\title{
What Parents Know: Risk and Responsibility in United States Education Policy and Parents' Responses
}

Amy B. Shuffelton

Loyola University Chicago, ashuffe@luc.edu

Follow this and additional works at: https://ecommons.luc.edu/education_facpubs

Part of the Education Commons

\section{Author Manuscript}

This is a pre-publication author manuscript of the final, published article.

\section{Recommended Citation}

Shuffelton, Amy B.. What Parents Know: Risk and Responsibility in United States Education Policy and Parents' Responses. Comparative Education, 16, 3: 365-378, 2020. Retrieved from Loyola eCommons, Education: School of Education Faculty Publications and Other Works, http://dx.doi.org/10.1080/ 03050068.2020.1724490

This Article is brought to you for free and open access by the Faculty Publications and Other Works by Department at Loyola eCommons. It has been accepted for inclusion in Education: School of Education Faculty Publications and Other Works by an authorized administrator of Loyola eCommons. For more information, please contact ecommons@luc.edu.

\section{(c) (†) $\ominus$}

This work is licensed under a Creative Commons Attribution-Noncommercial-No Derivative Works 3.0 License. (c) Taylor and Francis, 2020. 
What Parents Know: Risk and responsibility in United States education policy and parents' responses

Amy Shuffelton

Cultural and Educational Policy Studies, School of Education, Loyola University

Chicago, USA

Amy Shuffelton

School of Education, Loyola University Chicago

820 N Michigan Ave

Chicago IL 60611

ashuffe@luc.edu 


\section{What Parents Know: Risk and responsibility in United States education policy and parents' responses}

In this special issue exploring parents' responses to neoliberal policy changes, especially shifting notions of risk and responsibility, this article provides a historical account of local and national policy initiatives in the contemporary United States that have increased risk and placed responsibility for this risk on the shoulders of parents (as well as educators). The opening section of the paper reviews major recent policy documents and initiatives in the United States, from the landmark 1983 report 'A Nation at Risk' to the current age of test-based accountability. In the following sections, the paper explores what two Chicago parents themselves had to say about risk and responsibility in public schooling. What, in their views, were the actual risks? What did they think their responsibilities were, as parents? What did they do in response to the shifting policyscape?

Keywords: parents, parental involvement, neoliberalism, policy

\section{Introduction}

In this special issue exploring parents' responses to neoliberal policy changes, especially shifting notions of risk and responsibility, this article provides a historical account of local and national policy initiatives in the contemporary United States that have increased risk and placed responsibility for this risk on the shoulders of parents (as well as educators). The opening section of the paper reviews major recent policy documents and initiatives in the United States, from the landmark 1983 report 'A Nation at Risk' to the current age of test-based accountability. In the following sections, the paper explores what two Chicago parents themselves had to say about risk and responsibility in public schooling. What, in their views, were the actual risks? What did they think their responsibilities were, as parents? What did they do in response to the shifting policyscape? Chicago, as policy scholar Pauline Lipman has argued, is an excellent test case for analyses of contemporary education policy, because it has so often served as the incubator for ideas taken up at a national level, from housing reforms that affect the racial and socio-economic demographics of urban neighborhoods, to mayoral control, to test-based accountability and the de-unionization of the teaching force. Parents with children in Chicago Public Schools, a system underresourced, racially segregated, and subjected to neoliberal reform from the top down, 
therefore have an acute awareness of how policy changes put their children and their schools at risk, even as parents are asked to bear the responsibility for changes outside their control.

\section{Risk and Responsibility in the Policyscape}

'Risk' reconfigured the US landscape of educational policy - call it the policyscape following the publication of $A$ Nation at Risk (ANAR) in 1983. ANAR did not mince words. 'Our nation is at risk,' it began.

Our once unchallenged preeminence in commerce, industry, science, and technological innovation is being overtaken by competitors throughout the world. This report is concerned with only one of the many causes and dimensions of the problem, but it is the one that undergirds American prosperity, security, and civility. We report to the American people that while we can take justifiable pride in what our schools and colleges have historically accomplished and contributed to the United States and the well-being of its people, the educational foundations of our society are presently being eroded by a rising tide of mediocrity that threatens our very future as a Nation and a people (A Nation At Risk 2018).

From this opening declaration of the risks this 'rising tide of mediocrity' posed to the nation, the report turns in the second paragraph to the question of responsibility:

If an unfriendly foreign power had attempted to impose on America the mediocre educational performance that exists today, we might well have viewed it as an act of war. As it stands, we have allowed this to happen to ourselves. We have even squandered the gains in student achievement made in the wake of the Sputnik challenge. Moreover, we have dismantled essential support systems which helped make those gains possible. We have, in effect, been committing an act of unthinking, unilateral educational disarmament. ${ }^{i}$

The three claims that preface the report are thus 1) That Americans were at risk of losing political and economic 'preeminence,' 2) That education 'undergirds' the 
safeguards of the American way of life, and 3) That 'we' bore full responsibility for this risk.

Historian Diane Ravitch, who helped create some of the neoliberal reform policies that ANAR spawned in the two decades after its publication before she subsequently became one of education reform's most outspoken critics, provides a useful synopsis of what ANAR did and did not propose as the appropriate course of action. Its collar-grabbing opening was widely read and cited, but 'in winning public attention,' Ravitch says, 'the report dramatically overstated its conclusions'(2016, 28). Public schools were not in crisis; the economy, in a recession in 1983, soon rebounded; education was not wholly responsible for what political and economic problems the United States did have. Yet ANAR fostered a sense that schools were in need of a radical course-change. What was to be done? ANAR, Ravitch points out, notably did not call for the education reforms that followed. 'It did not refer to market-based competition and choice among schools; it did not suggest restructuring schools or school systems. It said nothing about closing schools, firing staff, promoting privatization, or instituting any other heavy-handed forms of accountability'(Ravitch 2016, 28). Instead, ANAR proposed 'conventional remedies,' such as stronger graduation requirements, more time on instruction and homework, and higher salaries for teachers. All the same, the language it used to declare a crisis laid the ideological groundwork for the embrace of risk and responsibilization that followed.

By 2002, ANAR's recommendations, as well as the teacher-designed national standards for school subjects that followed in the 1990s, were supplanted by a new reform plan for public schooling that relied heavily on market logic. The bipartisan No Child Left Behind act (NCLB) mandated that states use standardized tests to measure schools, relying on a mix of incentives and sanctions to reach the (unreachable) goal of ensuring that all children were proficient in literacy and mathematics skills by 2014 . NCLB was a complicated policy, but its key provisions included mandatory annual standardized tests for children in third through eighth grade. Schools had to disaggregate scores by race, ethnicity, low-income status, disability status, and limited English language proficiency, and show annual progress for every subgroup. Schools that did not make adequate yearly progress faced a series of increasingly punitive sanctions that could end with the school being closed. 
If ANAR introduced neoliberal discourses of risk and responsibility into educational policy, even as its recommendations were compatible with older notions of governmental provision of public schooling, NCLB injected actual risks into the bloodstream of American public schooling. Enacted in the wake of the 2001 terrorist attacks, at a moment when US citizens felt themselves at greater risk of harm from uncontrollable global forces than they had in decades, NCLB deliberately put every public school in the nation at risk of being closed. In doing so, it put administrators, staff, and teachers at risk of being fired. It put students and their families at risk of needing to make new arrangements for getting a K-12 education. Given the correlation between poverty and low performance on standardized tests, and the geographical concentration of extreme poverty in particular neighborhoods and their schools, those families least able to find new housing, childcare, and employment in order to send children elsewhere to school were at the highest risk of needing to do so. Market logic shaped both the policy and its effects. Schools were redefined as corporate actors and their students as clients; self-interest replaced professionalism as the presumptive motivator of quality work; failure led to replacement (with for-profit charters and nonunionized teachers, in many cases) rather than repair. Risk itself, the policy presumed, would spur improvement, though with no evidence to back this up, the plan itself was a risky speculation.

As for responsibility, NCLB narrowed considerably the 'we' who were responsible for public schools' shortcomings. In its sweeping claim that 'we' were responsible for the national security risk posed by our schools, A Nation at Risk recognized the entire nation as bearing responsibility for educating future generations of Americans. NCLB, on the other hand, laid the blame on the shoulders of educators and parents. Responsibility shifted from the public to individuals. In a nation that provided limited public health care, had recently restructured (and effectively reduced) welfare provisions for poor families, required all mothers to work full-time in order to receive benefits, guaranteed no maternity leave or sick leave, and mandated a minimum wage so low that a family could not live on it, NCLB's reconfiguration of education policy provided no accommodations for schools struggling to educate large numbers of impoverished children, even though hunger, untreated health conditions, and housing instability place extra hurdles in their educational pathways. ${ }^{\text {ii }}$ The US remains one of only 4 nations worldwide that does not guarantee maternity leave, which puts all 
mothers at acute risk of job loss and poverty. It bears mentioning that United States policies keep approximately $20 \%$ of American children below the official poverty line; to meet basic living expenses, a family needs approximately double the poverty threshold income, and by that measure, the number of American children in poverty exceeds 40\% (National Center for Children in Poverty 2018). Those numbers rose during the 'great recession' of 2008-2010. Yet there were no excuses for educators, parents, or children, politicians proclaimed. 'All children can learn' became the mantra of the era.

Education researchers have written extensively about how the responsibility to meet an impossible goal fell on teachers, as indeed it did. Less remarked is that it also fell on parents. NCLB includes multiple references to 'parents' and 'parental involvement,' rhetorically positioning parents as responsibility-holders and choicemakers. In Title I, the section of the policy that directs the allotment of resources for students from low-income families, Part A Subpart 1 Section 1118, 'Parental Involvement,' declares that to receive Title I funds, a local educational agency must implement 'programs, activities, and procedures for the involvement of parents in programs assisted under this part consistent with this section. Such programs, activities, and procedures shall be planned and implemented with meaningful consultation with parents of participating children.' NCLB was a rewrite of the 1965 Elementary and Secondary Education Act (ESEA), the law which first gave the federal government a major role in American schooling. Notably, ESEA does not use the word 'parent', or the gender-specific 'mother' or 'father.' It does include extensive references to 'families,' especially to the 'low-income families' it was designed to aid. The rhetorical difference indicates a functional difference. 'Families' lumps together parents with children, and in ESEA it is families who are the objects of public concern. NCLB's use of 'parents', in contrast, distinguishes parents - framed now as agents who play a role in carrying out the policy - from children, who remain the policy's objects.

This rhetorical shift both reflects and enforces a shift from ESEA's social welfare interpretation of public schooling as national responsibility and families as rights-bearing units of citizens and future citizens to NCLB's configuration of school as a market option with parents and children as individualized consumers. Viewed in a positive light, NCLB treats parents as agents, whereas ESEA treated them as recipients of state support, which is to say, as objects. Yet in according parents agency in regards 
to children's schooling, while simultaneously saddling schools with unreasonable demands, parents were given responsibility for a now-much-riskier endeavor. A further twist is that NCLB shifted more real power over education, which is not the same as responsibility, to the federal government and away from the local and state authorities more responsive to (and, in the case of America's local school boards, often constituted of and by) parents. Thus, as risk and responsibility were handed to parents, as well as educators, their power directly to manage their schools was curtailed. 'Steer this ship,' policymakers seemed to tell parents, 'while we attempt to scuttle it.'

Chicago was ground zero for many of the reforms that became national policy as NCLB and later, in NCLB's reenactment under President Obama, as Race to the Top. Chicago introduced test-based accountability measures in the 1990s, preceding the NCLB requirement that Illinois do so, started using them to close down public schools, and Chicago replaced democratic oversight of the city school system with a mayorally appointed CEO and school board. Chicago Public Schools' CEO in the early 2000s, Arne Duncan, took his market-driven reforms national when he was appointed Secretary of Education by President Obama in 2008. In Chicago, Duncan presided over the city's Renaissance 2010 plan, cooked up by Chicago's politicians and business leaders in 2003-04. Under Ren2010, Chicago Public Schools (CPS) planned to close 60 public schools and replace them with 100 new charter schools by 2010 . Duncan's signature achievement as Secretary of Education, the reissuance of NCLB as Race to the Top, required states to include provisions for replacing public schools with charters in order to qualify for large federal grants. Chicago, in Pauline Lipman's words, 'is more than a rich example. It is incubator, test case, and model for the neoliberal urban education agenda. Chicago is where big city mayors go to see how to restructure their school systems. . . Chicago is also a prominent case of the transformation of the industrial, Keynesian, racially segregated, city to the entrepreneurial postwelfare city' (Lipman 2011, 9).

Chicago Public Schools, the nation's third largest school district, is therefore an excellent place to look at how parents are facing the risks and the responsibilities that have been foisted on them by neoliberal education reform policies in the past two decades. As Lipman documents, education reform has worked in tandem with other urban reforms, notably in housing, to shift resources from poor and middle class city residents to the pockets of real estate developers and business elites. When $20^{\text {th }}$ century 
housing projects that sheltered Chicago's poor were demolished and replaced in the first decade of the $21^{\text {st }}$ century, the new mixed income housing did not include a comparable number of residences for low-income families. As a result, Chicago's (racialized mostly African American) poor moved out of Chicago in large numbers. Predictably, the population of school aged children dropped in those neighborhoods, and that drop became grounds for closing schools that were decreed 'underutilized' as well as 'failing.' Nonetheless, the (unelected) Board of Education approved charter schools in these same neighborhoods, further draining students from the remaining public schools and increasing city expenses, though this money now went to chartering agencies rather than unionized teachers, reducing the Board's obligations to Chicago's workers (whose benefits and pensions had to be paid) in the long run.

\section{Parents' Responses}

Curious to hear from Chicago parents how they perceived 'parental involvement' in the wake of these reforms, I interviewed parents whose children attended (or, in some cases, had attended but no longer did) Chicago Public Schools. ${ }^{\text {iii }}$ Interviewees were identified through their public involvement with a Chicago-based parent organization that advocated for increased resources for CPS schools, and then through snowball sampling, with interviewees directing me to other parents they considered 'exceptionally involved' with public schools. Selections from 2 of those 10 interviews, in which parents spoke about risks that concerned them, are presented below. I did not prompt parents to talk about 'risk,' and the parents did not use the word, but searching the interview transcripts for related affect words (e.g. worry, afraid) brought up instances of parents responding to risks that contemporary education policies have created. That search for affect-words related to risk led me to select the two interviews discussed in this article.

Because of methodological limitations, these parents' responses should not be considered representative. They are, however, informative. This project is meant to contribute to conversations about parents in political, social and ethical theory, insofar as such theory engages with empirical research -- as I think it must. Its disciplinary grounds are those of philosophy of education with a particular twist, as I and other philosophers of education have argued that epistemological common grounds shared by philosophical inquiry and qualitative inquiry into education make cross-disciplinary 
research, of which this project is an example, both fruitful and methodologically legitimate. ${ }^{\text {iv }}$ I hope the following will enrich the literature about parental involvement by providing some of parents' own rich accounts of their involvement with their children's educations. In enriching the theoretical conversations by engaging parents as interlocutors, I further hope to provide insights that empirical researchers can use in their work on parental involvement. All interviews were carried out by me. I asked interviewees for approximately half an hour of their time, and brought a list of questions, but in every case interviewees talked for longer, from approximately 45 to 90 minutes, and brought up what they thought was important for me to know, rather than sticking to my prompts. As the mother of two children in Chicago Public Schools myself, and a parent who shared many of my respondents' concerns about the direction of school policy, I found it easy to establish a rapport with other parents, which no doubt contributed to their responsiveness. This was most true of the middle-class and professional parents I interviewed, but it also helped establish rapport with low-income parents of color. In Chicago (and perhaps more generally?), children's school experiences are what mothers frequently turn to as a conversation starter when they meet other mothers with school-aged children, a conversational convention that worked to my advantage in this research project. My position as a CPS parent influenced this study in many other ways as well, from the study's conception to my analysis of the interviews.

Before moving into the interview accounts, two other relevant factors of the policyscape merit mention, as they are as easy for international readers to overlook as for American readers to take for granted. The first has to do with responsibility. Public schooling in the United States has throughout its history been far more decentralized and subject to local control than in other industrialized nations. Public schooling has been supported primarily by local property taxes, and democratically elected school boards have had a great deal of oversight. Due to school boards, in fact, a significant percentage of American citizens hold elected office, and an even larger number attend public school board meetings. The diminishment of local control is thus, for all the problems with local control (especially racial segregation of schools), a blow to Americans' direct experiences with democratic self-governance. In her interview, Phuong expresses concern about this. The US education system can appear fragmented 
and incoherent; to its proponents, it represents democratic self-governance and the right of parents to determine the education of their own children.

The second reminder is about risk. Guns, keep in mind, are omnipresent in Chicago (as in the United States generally). Neoliberalism's replacement of social welfare ideology has coincided with the radicalization of the National Rifle Association (NRA), which used to be a sportsman's association but has, in the past 50 years, become a major political influence, supporting the loosening of America's already liberal gun laws. At present, there are estimated to be more firearms in the United States than there are people. Addressing the material reality that guns create risks, furthermore, is complicated by gendered and racialized rhetoric, promulgated by the NRA, that casts some people (Black, Latino, youth) as 'risky' gun-bearers who make it necessary for other people (White, men, especially husbands and fathers) to own more guns. There are, in short, a lot of guns in Chicago, with gun violence concentrated more in some neighborhoods than others, but requiring all parents to think about their children's risk of getting shot - and, as the reader can hear echoed in Angela's interview, about their children's safety as they grow into the less adult-supervised social life of adolescence. This gives risk, and parents' worry, a particularly American twist.

\section{It is almost panic time: Phuong}

Phuong described the neighborhood school that her two daughters attended as a 'gem in the city.' A refugee when she came to the United States from Vietnam as a child, Phuong had earned an advanced degree in ethnobotany, which inspired her to develop a gardening program with her neighborhood school, where most of the students were Mexican American. Phuong was already planning the next year's gardening program, which she took a few months leave from her job as co-owner of a small family business to carry out. Working with 17 teachers and approximately 280 schoolchildren, she taught practical 'garden lessons' about how to grow plants from seed to harvest but also 'really dug back into my ethnobotany and talked to the kids really about botany. Really 101 stuff, but trying to tie in these bigger global issues and also local issues of foods. Just trying to change our relationship with plants and food. And it was just so rewarding that I am like we have to do it!' In Phuong's view, the garden program provided a means for immigrant children to stay connected to traditional, healthier 
foodways - 'that we used to -- you would have to grow your own foods.' It was 'poignant,' she said, to see children's excitement when their seeds sprouted.

Phuong took responsibility for the school; she also recognized risks it faced as a result of decisions made by the city and the state. In December 2015, when we spoke, Illinois had not passed its annual state budget (nor would it pass one until 2017), and although stopgap measures were passed so that schools could operate, CPS was severely short of funds. Meanwhile, in November 2015, CPS CEO Barbara Byrd Bennett had been indicted on corruption charges related to a kickback scheme, for which she would eventually be convicted and jailed. Phuong appreciated what her school's principal was doing in the face of constant financial pressure, but she thought a stronger response was called for. 'Even with all the burdens,' Phuong said, 'this school continues to really try to meet the needs of the kids.' Recent events, however, seemed to her to be taking a toll on the principal's morale.

And for good reason -- of course we all know why. But it has even gotten to where ... the things she was saying [to parents at a recent holiday breakfast for volunteers]... it was very doomsday. Doomsday in the way that wasn't like 'hey we can do something about it. . . . I really wish she would be more, sort of, not a rebel, but even more of just like putting that out there. Even at LSC [Local School Council] meetings, this is my second year on the LSC, and I often felt like last year I would say things about opting out or really voicing my opinion about the park and I would just feel like, it's never like she would hush me, but it was this consensus that she just doesn't want to panic. Like cause panic in the teachers. Cause panic in the parents. And I am more like it's time to wake people up and actually cause them maybe not to panic, but we can strategize before we have to panic, because now it is almost panic time.

As her words make clear, Phuong had a nuanced understanding of the risks to parents, teachers, and communities. She, like many politically engaged Chicago parents, thought CPS was partly to blame for its fiscal woes (e.g. by hiring corrupt CEOs and opening new charter schools even as district enrollment was falling), and she recognized that the risks were handed down to individual schools as demands for achievement alongside reductions in resources. She recognized also that speaking out could be a risk, especially for parents who were not citizens. She responded to the risks facing her school by getting involved, in two distinct ways. She volunteered her time to 
the gardening program. She also called for political involvement: through the elected Local School Councils, through collective testing opt-out, and through engagement with elected officials. Volunteering, which entailed forgoing paid employment for several months, and opting out of tests put Phuong at risk. But for Phuong, it was better to take those risks, in the hope of preventing other harms, than to let 'people in power . . keep us where they want us.'

Phuong viewed the accountability measures imposed on schools as a waste of money the cash-strapped district could ill afford. She considered testing opt-out to be a means of forcing CPS listen to what parents wanted. 'For us it doesn't matter what the kids really score on their test,' she told me. 'The fact that they are just so loved and nurtured [at their school] is huge for us.' In opting her children out of standardized testing, Phuong was part of a movement of American parents who oppose the tests. As Oren Pizmony-Levy and Nancy Green Saraisky report, based on their survey research, parents offer a range of reasons for opting their children out of standardized tests. Reasons stretch across the political spectrum, from libertarian objections to federal authority over local schools to progressive resistance to the tests' effective penalization of schools serving children in poverty. Phuong objected because she saw the tests as a waste of resources, an inappropriate measure of school quality, and an unwarranted imposition by an unelected school board (Pizmony-Levy and Saraiski 2016) . Nor did her political speech stop there. 'To be honest,' she wanted to tell her fellow parents at the breakfast, 'I don't think folks downtown [at CPS central office] really care about our building coming apart -- like in the gym where we have the breakfast these wooden panels are literally coming off, and we have been trying to do a fundraiser for over a year and a half to get new curtains. The curtains that we have have been there since the Roosevelt administration, or something insane.' The morning of the breakfast, the neighborhood's State Representative to the Illinois legislature was visiting the school's student council, and she urged parents to go talk to him.

To address the funding crisis hitting CPS schools like hers, Phuong thought parents needed to take collective action. 'I truly believe that small changes, just small little things, make big differences,' she told me. 'When you drop anything in water that ripple goes and it's going to continue. And whether the change is going to happen, of course in my lifetime... I am like 'put that aside now'. I am like 'that's probably not going to happen'. But hopefully if it can happen, it might for my daughters, or their 
kids should they have kids or whatever, but just generations from now I feel like it is possible. The first step, I think, is just to really get the parents to be aware that they do have a voice.' Phuong recognized that in calling for immigrants to speak out, there was a 'sensitive line that we have to always be keeping in mind,' but, she added, 'I also do feel for them, like, 'you know what, I do understand your concerns, but I also feel like that is just another fear. You know, that people in power do put on us. And that makes us, you know, it sort of does keep us where they want us." After addressing some of the objections to testing opt-out, and telling me how she came to be involved with the school. Phuong returned to the importance of political action. She turned to plants as a metaphor. 'Ahh, [gardening] has such an immediate sort of wakening effect. And I think in that principle of like you know, like I said earlier, I've been resigned to say change might not happen in my lifetime but if I can plant that seed ....'

\section{As long as you teach your child you don't have nothing to worry about: Angela}

In Angela's account of her two children's schooling, immediate risks played a powerful role. Angela's children had attended three schools: a charter school, a neighborhood elementary school, and a lottery-based magnet school. She moved her daughter from the charter to the neighborhood school after second grade because the charter stopped providing bus service, making 'school choice' an unavailable choice. But she had other reasons as well. 'One of her kindergarten teachers when I was there told me that I should get her out of that school because the school wasn't good for her. And when I switched her over to [the neighborhood school] I found out that was true because my daughter was still at a first grade level. She was going to third grade and she wasn't nowhere near the third grade level. So they had to take my baby back and they found out that she had dyslexia. And [the charter school] knew something was wrong, but they wasn't trying to pay attention. ${ }^{\text {vi }}$ Angela, who is Black, suspected that her daughter's neglect by the charter school was affected by race. Her new teachers 'worked really good with her compared to the charter school she went to, which was mostly Hispanic. And in [the charter school] they had my daughter, like it was a guy, it was a little child who did not know English so she had to sit by him and help him with his homework.' Angela, like Phuong, responded to her worries about school by getting involved, but differently. 'I did not like that idea. I told them to stop. So I decided to sit there and watch them, how they teach. I did not like the way they teach. I didn't like it at all.' 
She kept up her vigilance at the neighborhood school, and she thought all parents had a responsibility to do the same. 'Like they say, as long as you teach your child you don't have nothing to worry about. As long as you stay on your child and show them what behavior is, what's bad behavior, what's good behavior, you don't have nothing to worry about. And by me volunteering in the school I was always in the school, was always there every day, became a PAC [Parent Advisory Council] chair, was on the LSC, you know I built a lot of things with the school. So what I noticed is that when you are involved with your child in school, the teachers stay focused on your children because you are there. You see what is going on.' ${ }^{\text {vii }}$ Angela lamented that 'a lot of parents, especially in my race, don't have, don't do that.' Rather than blame parents, though, she took upon herself the responsibility for helping them work through problems with the school. 'We don't communicate with the teachers. Most of them are always fussing at the teacher, not trying to listen to each other about what's going on and how to help the child. But what I used to do as the PAC chair -- every time a teacher had a problem with a parent I always sat there and listened to help the teacher out as well as the parent out. So if I feel like the parent is wrong I would butt in and say no. This is this, and you need to do this, and they would listen to me.'

For all her involvement with the neighborhood school, Angela's children no longer attended it. She had moved them to a lottery-based magnet in a different neighborhood because 'some of the neighborhood kids was horrible. I just didn't want my daughter to pick up their bad habits. It wasn't the teachers, it wasn't the principal, it was the children that I was afraid of for my child. That was it.' She worried even more about her son, whom she described as 'a follower.' She did not mention worrying that the neighborhood school might be closed, though it was on the list of 54 schools CPS planned to close in 2013, but this may have been an additional consideration. At the magnet school, Angela was no longer serving on the PAC or the LSC, though she was present in the school, working as a custodian. She had taken that job when her son started attending, in first grade, so that she could keep an eye on him, which she felt she needed to do. 'I am in the school when he in the school. I am in the school from 6-2:30. He is there from 7:30-2:30, so I am there all day. I can go check on him when he's on lunch. I can go check on him when he's on recess. I can do all those things.'

She wanted her children's lives in school not to repeat her own school experiences. 'I was bullied all the way from when I was a little kid . . because I wore 
glasses and I didn't dress like everyone else. Like, glasses are popular now. Back in my days, it wasn't popular. No, you got teased, jumped, beat up. And I didn't dress like everyone else. So when I was in high school I couldn't take it. They was jumping me every day out of school.' She dropped out after her freshman year. Once she had children, however, she reflected back on conversations with her own mother, whose advice to stay in school Angela had dismissed because her mother had also dropped out. 'I used to be like 'you didn't stay in school how are you going to tell me?' So I went back to school, got my GED, and then I went to college and got my Associates degree. So my daughter she watched me through the process, she even cheered me on. I even let her make comments about my grades. Like I show her my grades, and she be like 'mom I don't like that C, you need to bring it up.' I'm like 'I'm gonna try, I do need to bring that up.' . . . So I let her voice an opinion about my grades, so that she can see how important it is when I get on her about her grades.' If in some respects Angela seems like a stereotypical 'helicopter parent,' there are important differences. Angela intervened in response to risks that were real and imminent, like unaddressed dyslexia, rather than imaginary or distant in time. She also recognized that the example she set was one of her best means of influencing her children's decisions as they grew old enough to make them for themselves, and she shared authority by subjecting her school achievement to her daughter's judgment as well as her daughter's to hers.

Furthermore, Angela did not limit her attentiveness to her own children. When I asked her how parents at the neighborhood school felt about her sitting in on their conferences with teachers, she told me they were willing to listen to her 'because the children love me. They all call me mama. And I fuss at them like they are my kids. I still do that, if I see them outside, most of them are in high school, if you walk with me they be like 'hey mom.' So. I treat all of them like they my kids. If I see them doing something I'll holler at them too.'

Angela's name was suggested to me because the neighborhood school her children had attended was designated for closure in 2012-13, and, like Phuong, Angela had connected with an organization of parents mobilizing to support public schooling in Chicago. Now that her children had moved to a magnet school, however, Angela no longer had a formal parent leadership role within the school. 'I am just cleaning and listening,' she told me. The principal at the magnet school, she said, 'wants people that clean to be out of the ... don't be in the open. The teachers are beautiful -- they nice. I 
am always speaking to them. They open up. But the person that has the nerve to speak up, [for] leadership and commitment and teamwork, is not [treated by the principal as] a team player.' So she cleaned and listened, doing her best to ensure that her children got a solid education, certain that she, not professional educators or the system that employed them, had to take responsibility for that.

Angela's story speaks to obstacles in the path of a democratic approach to making school both excellent and equitable. Angela was thoughtful, disciplined, and seemed to have a knack for getting children, parents, and educators to work together. In a world that had protected her from the bullies and provided a high quality education to all students, she might have done great things with those abilities. In a world that failed her as a teenager but provided second chances through the GED and community colleges, she had become a leader within her school and neighborhood. The systematic destabilization of schools and neighborhoods drove her out of the neighborhood school where her leadership was appreciated, into a mixed-race school, where her involvement was not invited. Linn Posey Maddox has documented how the reengagement of white parents with urban schools has lifted the test scores and graduation rates of schools attended by white children but pushed Black parents out of those schools and neighborhoods that had been, however imperfectly, theirs. Angela experienced this dynamic in two ways: as white families moved to the city, real estate value in her neighborhood appreciated and the city had reason to close and sell school buildings, and when she moved her children to a mixed race school, her leadership abilities went unrecognized (Posey-Maddox 2014). In a democracy debilitated by racial inequality, Angela was left cleaning up the messes that others were making.

Technocratic solutions, however, have been no panacea either. While urging 'parental involvement' in public schools, CPS's Board of Education ignored the pleas of thousands of parents who turned out to beg CPS not to close their neighborhood schools, assuring parents that children would receive a superior education under its plan. Five years after the 2013 closure of 49 CPS schools, a recent study shows that children whose schools were closed are faring no better. 'Did closing schools provide students with better educational opportunities and stronger academic outcomes?' the

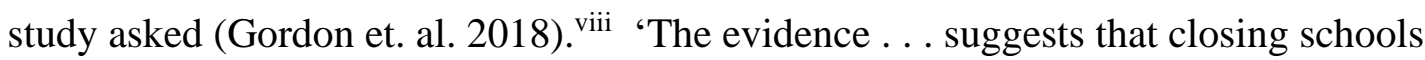
and moving students into designated welcoming schools to consolidate resources did not automatically expose them to better learning environments and result in greater 
academic gains.' According to the researchers, 'In this and other previous studies on the effects of school closures, we have seen that academic outcomes, on average, do not improve after students' schools were closed.' Furthermore, it created new problems, such as distrust and low morale among parents and teachers affected by the closures. As for solving other long term problems, the study noted that five years later the budget remains tight and enrollments continue to decline. The Board of Education, meanwhile, continues to open new charter schools, and after a five-year moratorium on school closures, in 2018 it closed all the remaining neighborhood public schools, including the high school, in the Black neighborhood of Englewood.

\section{Technocracy or Democracy?}

The policies discussed in this paper, and the interviews that present two exceptionally engaged and thoughtful parents' responses to them, can be understood as part of an ongoing argument between American citizens who agree that federal authority over education, assigned to technocratic policy professionals, would fix longstanding problems of school quality and inequality and American citizens who believe that democratic control is a better path than technocratic fixes to achieving long-lasting solutions. To date, the technocrats have not fixed the problems; whether democracy could do better remains an open question.

Test-based accountability regimes, and the reconstitution of a public system as a market system by means of school closures and charter schools, are technocratic approaches to the extraordinarily complex problem of educating children. Their legitimacy rests on the premise that mastery of information, nearly all of it quantitative, will enable master technicians - namely policy makers at the district, state, and federal levels - to tinker with the implementation of programs in order to bring about desired results. This premise is profoundly apolitical. It harkens back to a debate between Walter Lippman and John Dewey in the 1920s, a time when the United States was also struggling to address the massification of social services, an influx of recent immigrants, and a changing international role. Lippman argued, in his influential book Public Opinion, that since the foundation of the United States as a republic in the $18^{\text {th }}$ century, technological changes to work, communications, and daily life had rendered the affairs of the government sufficiently complicated that the founders' premises of an 'omnicompetent citizen' were no longer plausible. Lippman doubted that the 
Jeffersonian premise that citizens were ever qualified to vote on all matters had ever held, but in any case, he argued, the modern complexity of problems and the wealth of extant information made it less credible than ever. Government, Lippman argued, should be in the hands of experts.

John Dewey reviewed both Public Opinion and Lippman's subsequent book about voter apathy, The Phantom Public favorably in the New Republic, but although Dewey thought Lippman had accurately diagnosed a significant problem, he disagreed with Lippman's solution (Dewey 1983, 340). ${ }^{\text {ix }}$ Publics, Dewey argues, form as members of a community come to recognized the '[i]ndirect, extensive, enduring and serious consequences of conjoint and interacting behavior'(1983, 110). Called into existence by this shared recognition of consequences, publics have 'a common interest in controlling these consequences' (Dewey 1983, 110). Dewey agreed with Lippman that 'the machine age has so enormously expanded, multiplied, intensified and complicated the scope of the indirect consequences, has formed such immense and consolidated unions in action on an impersonal rather than a community basis, that the resultant public cannot identify and distinguish itself' $(1983,110)$. Yet experts will never be able to solve political problems without the input of citizens, Dewey argues, because those affected by a problem are those best positioned to identify what, precisely, the problem is. Too removed from the consequences - those frayed curtains from the Roosevelt era, those charter schools that neglect a Black first grader's dyslexia, those White principals who even as they claim to advocate for racial equity prefer that Black cleaning staff stay out of sight - experts are unable to grasp the consequences as only the public can. In Dewey's words, 'the man who wears the shoe knows best that it pinches and where it pinches, even if the expert shoemaker is the best judge of how the trouble is to be remedied.' The problem, for Dewey, is that a 'class of experts' - e.g. technocratic education policy makers - 'is inevitably so removed from common interests as to become a class with private interests and private knowledge, which in social matters is not knowledge at all'(1983, 154). For Dewey, there is a role for expertise and an essential role for publics that come together around shared problems.

Phuong's and Angela's responses to educational policy in Chicago, from testbased accountability to school closures, represent the kind of public involvement that Dewey recognized as essential. They were involved parents, participants in what Dewey would recognize as a public that formed around a conjoint recognition of 
consquences, but not in precisely the mode that NCLB, state and Chicago Public Schools recognizes and mandates. In Phuong's case, parental involvement included resistance to official policy as well as cooperation with her local school. In Angela's case, parental involvement was valued by a mostly Black school that ultimately faced closure and then devalued by a mixed-race school praised as one of the city's best. Their stories suggest the limitations of policy solutions that fail to attend to parents' own experiences of risk and responsibility within public schooling. Phuong's and Angela's insights suggest also the need to engage the wider public, including but not limited to parents and teachers, in taking responsibility as citizens for the real risks facing America's schoolchildren. Dewey would recognize their knowledge about the problems facing their schools as the kind of social knowledge more relevant to public problems than policy-makers' quantified knowledge that, insofar as it is removed from what parents, teachers and students know, is no knowledge at all. In sharing their words with the wider audience reading this journal, I hope to have given their knowledge the place at the table it deserves. 


\section{References}

A Nation at Risk .April, 1983. accessed 5/6/2018 at

https://www2.ed.gov/pubs/NatAtRisk/risk.html

DeParle, Jason. 2005. American Dream. New York: Penguin.

Dewey, John. 1983. "Public Opinion.” In The Middle Works of John Dewey, edited by Jo Ann Boydston, vol. 13, 1921-1922, 340. Carbondale: Southern Illinois University Press.

Dewey, John. 1954. The Public and its Problems. Athens, Ohio: Swallow Press. 109

Ewing's, Eve. 2018. Ghosts in the Schoolyard: Racism and School Closings on Chicago's South Side. Chicago: University of Chicago Press.

Gordon, Molly, Marisa de la Torre, Jennifer R. Cowhy, Paul T. Moore, Lauren Sartain and David Knight. 2018. "School Closings in Chicago." Chicago: University of Chicago Consortium on School Research.

Hays, Sharon. 2003. Flat Broke with Children. New York: Oxford University Press.

Lipman, Pauline. 2011. The New Political Economy of Urban Education. New York: Routledge. 19

Moses, Michele. 2015. "Introduction on non-ideal theory in philosophy of education." Educational Theory, 65 (2).

National Center for Children in Poverty website http://www.nccp.org/topics/childpoverty.html accessed May 14, 2018

Pizmony-Levy, Oren and Nancy Green Saraisky. 2016.“Who Opts Out and Why?” New York, Teachers College.

Posey-Maddox, Linn. 2014.When Middle-Class Parents Choose Urban Schools: Class, Race, and the Challenge of Equity in Public Education. Chicago, University of Chicago Press.

Ravitch, Diane. 2016. The Death and Life of the Great American School System. New York: Basic Books. p 28

Shuffelton, A. 2014. "Estranged Familiars." Studies in Philosophy of Education. 33 (3): 137-147.

\footnotetext{
${ }^{\mathrm{i}}$ emphasis added
} 
ii On welfare-to-workfare reforms of the 1990s and their effect on parents and children, see Sharon Hays. 2003. Flat Broke With Children. New York: Oxford; Jason DeParle. 2005. American Dream New York: Penguin.

iii The interviews were transcribed by my graduate assistant, Samantha Deane, for whose help I am grateful. All names of interviewees are pseudonyms. I have edited speakers' words slightly for sake of clarity by trimming filler words but have otherwise quoted them directly.

${ }^{\text {iv }}$ See especially Shuffelton, A. May 2014. 'Estranged Familiars.' Studies in Philosophy of Education 33 (3): 137-147; c.f. other articles in that issue. See also Educational Theory 65 (2) 2015, especially Michele Moses's introduction on non-ideal theory in philosophy of education.

${ }^{\vee}$ I have written more about parents and testing opt out in 'Opting Out or Opting In? Test Boycott and Parental Engagement in American Public Education,' forthcoming Educational Theory.

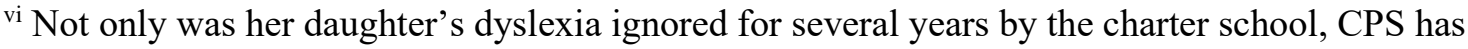
been no model for upholding special education law. In May 2018, its special education program was put in state hands, after an investigation uncovered systematic delay and denial of services to students. Although Angela was satisfied with the services her daughter received (prior to 2016, when policy changes created the problems identified by the state investigation), it is important to recognize that her vigilance was not paranoia. Parent complaints about the effects of the new policies on their children drove the media reports that drove state action.

vii PAC stands for Parental Advisory Committee. These committees were established in Chicago Public Schools in response to the requirements in NCLB, cited above.

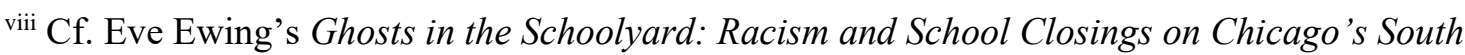
Side, 2018.

${ }^{\text {ix }}$ I have discussed this at greater length in [reference scrubbed for peer review] 